\title{
Convenience Yield Value of International Emission Allowance Based on Call Options
}

\author{
Kai Chang \\ School of Finance, Zhejiang University of Finance \& Economics, Hangzhou 310018, China \\ Correspondence should be addressed to Kai Chang; kchang16@163.com
}

Received 26 December 2013; Revised 10 May 2014; Accepted 21 May 2014; Published 30 June 2014

Academic Editor: Arash Massoudieh

Copyright (C) 2014 Kai Chang. This is an open access article distributed under the Creative Commons Attribution License, which permits unrestricted use, distribution, and reproduction in any medium, provided the original work is properly cited.

Convenience yield is call options; spot holders attain excess investment revenues through holding spot assets instituted futures assets. Based on the hypothesis of convenience yields, our empirical results show that monthly convenience yield of emission allowance has significant options feature; convenience yield has strong correlation with price spread between spot and futures and their price volatility. The market information set is helpful to adjust portfolio policy and improve portfolio investment revenues of emission allowances.

\section{Introduction}

Greenhouse gas (GHG) emission is an ever increasingly hot topic in the 21st century for alarming phenomena of global warming and extreme climate deterioration. Emissions trading scheme is cost-effective market scheme in order to prevent climax changes and control greenhouses gas (GHG) emissions reduction [1-3]. Spot, forwards, futures, options, and swaps are of important financial tools for market participants to increase assets portfolio returns and strengthen risk reduction management. According to research report on state and trend of carbon market in 2011 by the World Bank, the total value of the global carbon markets grew 6\% to US $\$ 144$ billion until 2010; its trade volume attained 8.7 billion tons $\mathrm{CO}_{2}[1]$

Spot and futures prices of emission allowance crucially depend on expected market scarcity induced by total quantity of demand and supply in the emission allowance market, and many complex factors such as GHG emission reduction planning and regulation policy, low-technology promotion and application, energy price volatility, energy efficiency, and extreme temperature change have significant impacts on the scarcity in emission allowance market $[2,3]$. Several empirical results show that spot and futures prices exhibit obviously time-varying trends. Seifert et al. [4], and Benz and
Trück [3] present that spot prices of emissions allowances show a time-varying trend; Seifert et al. find that spot price exhibits a time- and price-dependent volatility structure [4]; Benz and Trück examine that spot price volatility exhibits a left-skewness and heave-kurtosis trend in the Pilot and Kyoto phase [3]. Daskalakis et al. find that bankingborrowing regulation prohibition has a significant impact on spot and futures prices; market participants can achieve market arbitrage incomes through optimizing assets portfolio policy between futures and options markets in the Pilot and Kyoto phase [5]. Chang et al. propose a new N-factor affining term structure model of futures price of emisssion allowances and their empirical results show that futures price and convenience yields follow a significant mean-reversion process in the Kyoto phase [6]. Chang et al. propose a general model of futures options valuation under the term structure of stochastic multifactors; their empirical results show term structure of stochastic multifactors has a significant effect on futures options valuation of $\mathrm{CO}_{2}$ emissions allowances and estimate the theoretical futures options valuation by using historical market information [7]. The above empirical results examine that spot prices, futures prices, and their volatility exhibit obviously time-varying trends, and thereby spot and futures of emission allowances are all higher risks. 
This paper has two major contributions, based on Chang's results; convenience yield implied from futures market exhibits a significant options feature, his empirical result shows that convenience yields exhibit call options feature $[8,9]$. Firstly, convenience yield is call options; we estimate monthly options value of convenience yield based on the extension of Margrabe's options pricing model of assets exchange and then propose empirical evidence driving factors of monthly options value of convenience yield. Secondly, our evidences show that monthly options value of convenience yield is negatively related with price spread both spot and futures assets, and monthly options value of convenience yield is positively related with spot price and futures price volatility and also negatively related with futures price and spot price volatility. The remainder of our paper is organized as follows. Section 2 presents options pricing model of convenience yields of emissions allowances. Section 3 proposes three hypothesis of monthly options value of convenience yield. Section 4 describes data source and discusses empirical results of their hypothesis. Section 5 provides a brief conclusion.

\section{Options Property of Convenience Yield of Emission Allowance}

Based on cost-of-carry theory, commodity convenience yield denotes revenue measure of holding certain storage level in an uncertain market condition [9]. Commodity convenience yield is significantly related with commodity production, storage level, transportation cost, and other related costs. Emission allowance is a special credit commodity; holding emission allowance quotas need not storage cost, and thereby the convenience yield is the difference of expected price between spot and futures assets of emission allowance based on risk-free interest rates.

The convenience yield denotes excess opportunity cost paid by futures holders of emission allowance. When unexpected market demands assault emission allowance market, market supply will not be significantly increased in the short term; the scarcity of emission allowance market will increase, and then raising speed of spot price is greater than raising speed of futures price; accordingly spot holders can attain excess investment returns through exchanging spot and futures assets. If expected spot price is greater than futures price of emission allowances on the basis of risk-free interest rates, convenience yields are positive; convenience yield is call options, and spot holders of emission allowance can gain extra options value through purchasing spot assets while selling futures assets. If expected spot price is less than futures price, convenience yields are negative, and then convenience yield is a put option. Market participants can take contrary portfolio policy through purchasing futures assets while selling spot assets; futures holders of emission allowance can gain extra options value. Accordingly market participants flexibly adjust portfolio policy between spot and futures using options feature of convenience yield, can effectively avoid market transaction risk induced by price volatility, and then achieve extra market arbitrage revenues.

\section{Hypothesis Development and Model Estimation}

Many empirical results show that convenience yield is call options; many scholars can estimate options value of commodity convenience yield using Black-Scholes options pricing model and exchange options pricing model. Milonas and Thomadakis present empirical evidence on the storage commodities of soybeans, corn, wheat, and copper, and their results show that convenience yield is call options; its options value is related with underlying assets, the maturity of futures contract and strike price [10]. When futures price is very sensitive to convenience yields, the options-call feature of convenience yields cannot be ignored. Kocagil examines options value of commodities convenience yields, and his results indicate that marginal cost and spot prices have significant effects on options value of commodities convenience yields [11]. Lin and Duan propose that commodities convenience yields are negatively related to inventory level of underlying crude oil and positively related to interest rates; convenience yields may explain price spread between WTI crude oil and Brent crude oil [12]. Assumed that market investors are riskneutral, strike cost of assets exchange between spot and futures is equal to zero; spot price $s_{t}$ and futures price $f_{t}$ follow Brownian motion. Consider the following:

$$
\begin{gathered}
d s_{t}=\mu_{s} s_{t} d t+\sigma_{s} s_{t} d z_{s}, \\
d f_{t}=\mu_{f} f_{t} d t+\sigma_{f} f_{t} d z_{f},
\end{gathered}
$$

where $s_{t}$ and $f_{t}$ denote the logarithm of spot and futures price of emission allowance, $\mu_{s}, \mu_{f}$ denote instantaneous returns of spot and futures price, $\sigma_{s}$ and $\sigma_{f}$ denote market volatility of spot and futures price, which do not vary in the period of assets holding, and $d z_{s}$ and $d z_{f}$ denote the increment of a standard Wiener process, and $d z_{s} d z_{f}=$ $\rho d t$, where $\rho$ is related coefficient between spot and futures price, and related coefficient $\rho$ is constant in the period of asset exchange. Assumed risk-free interest rate is $r, f_{t}=$ $F(t, T) e^{-r(T-t) / 365}$ denote discounted futures price of emission allowance. We propose the extension of Margrabe's options pricing model of assets exchange in order to estimate options value of convenience yield of emission allowance. When $\mathrm{OCY}_{t}>0$, spot holders of emission allowance can gain extra convenience yield, and market investors have an option to buy spot assets while selling futures assets; convenience yield value is equal to $[9,10]$

$$
\begin{gathered}
\mathrm{OCY}_{t}=s_{t} \phi\left(d_{1}\right)-f_{t} \phi\left(d_{2}\right), \\
d_{1}=\frac{\ln \left(E\left(s_{t}\right) / E\left(f_{t}\right)\right)+\left(\sigma^{2} \tau / 2\right)}{\sigma \sqrt{\tau}}, \\
d_{2}=\frac{\ln \left(E\left(s_{t}\right) / E(f)_{t}\right)-\left(\sigma^{2} \tau / 2\right)}{\sigma \sqrt{\tau}}=d_{1}-\sigma \sqrt{\tau}, \\
\sigma^{2}=\sigma_{s}^{2}+\sigma_{f}^{2}-2 \rho \sigma_{s} \sigma_{f},
\end{gathered}
$$

where $E\left(s_{t}\right)$ and $E\left(f_{t}\right)$ denote average value of spot price and discounted futures price in the period of assets exchange, 
$s_{t}(0)$ and $f_{t}(0)$ denote spot price and discounted futures price at the initial period of assets exchange, $\tau$ denote assets-holding period, and $\phi(\cdot)$ is normal distribution. $\mathrm{OCY}_{t}$ denotes options value of convenience yields of emission allowances.

On the basis of Chang's empirical results $[8,9]$, market participants freely select holding assets through exchanging assets between spot and futures. Positive convenience yield is call options, and market participants gain extra investment returns through holding spot assets while selling futures assets; accordingly we believe that those arbitrage returns similarly denote call options using options feature of convenience yield. Negative convenience yield is put options, and futures price is greater than expected spot price of emission allowances; market participants have the options to buy futures assets while selling spot assets, and then they can gain extra arbitrage revenues using options feature of convenience yield.

Hypothesis 1: Convenience Yield of Emission Allowance Is Positively Related with Price Spread between Spot and Futures Assets. Excess market demand promotes spot price a rapidly increasing trend with the price spread enlargement between spot and futures assets. Shorten price spread sigmals directly reflect the speed changes of spot price and futures price, and speed changes of spot price is greater than futures price. Spot holders of emission allowance can obtain a higher convenience yield. In order to examine convenience yield change, we present the following regression equation:

$$
\mathrm{OCY}_{t}=\alpha_{1}\left(s_{t}-F_{t}\right) \text {, }
$$

where $s_{t}-F_{t}$ denote price spread between spot and futures assets and $\alpha_{1}$ denote their coefficient. If expected spot price is greater than futures price at time $t$, convenience yield is positive; market participants can gain extra convenience yields, and then convenience yield is call options. Futures price is greater than expected spot price; convenience yield is negative, and then convenience yield is put options. As a result, we propose the hypothesis that monthly options value of convenience yield is positively related with price spread between spot and futures assets.

Hypothesis 2: Convenience Yield Is Positively Related with Spot Price and Futures Price Volatility, and It Is Negatively Related with Futures Price and Spot Price Volatility. Pindyck, Wei, and Zhu find that commodity convenience yield is related with spot price, volatility, and inventory level $[13,14]$. Kremser and Rammerstorfer (2010) present that commodity convenience yield is related with spot price, futures price, their volatility, interest rate, and previous convenience yield [15]. Based on cost-of-carry theory, convenience yield value is denoted by $c c y_{t}=s_{t}-f e^{-r \tau}$, and accordingly convenience yield is related with spot price, futures price, and their volatility. Consider the following:

$$
\mathrm{OCY}_{t}=\beta_{1} s_{t}+\beta_{2} \sigma_{s t}^{2}+\beta_{3} f_{t}+\beta_{4} \sigma_{f t}^{2},
$$

where $s_{t}, \sigma_{s t}, f_{t}$, and $\sigma_{f_{t}}$ denote spot price, futures price, and their volatility and $\beta_{1}, \beta_{2}, \beta_{3}$, and $\beta_{4}$ denote the coefficients of each variables.

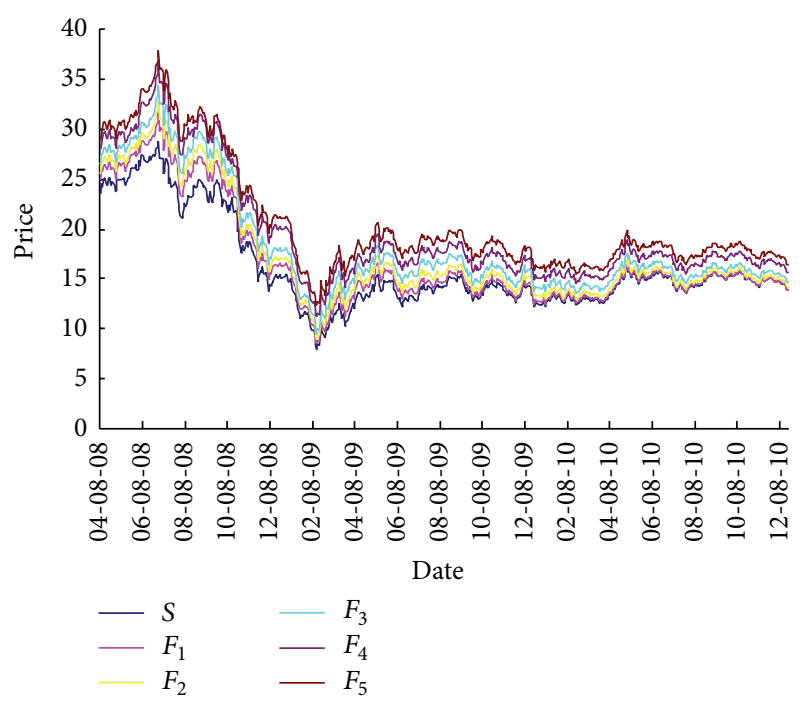

FIGURE 1: Price serial both spot and futures contracts with different maturities.

\section{Data Source and Hypothesis Estimation}

4.1. Data Source. European Union emissions allowances markets have existed two phases: the Pilot phase (2005-2007) and the Kyoto phase (2008-2012). In this paper, we choose empirical date samples which are from the most liquid and largest $\mathrm{CO}_{2}$ spot and futures exchange platform in the $\mathrm{EU}$ ETS. One European Union allowance (EUA) has the right to emit one tone $\mathrm{CO}_{2}$ into the atmosphere under the $\mathrm{EU}$ ETS. The minimum trading volumes for each futures contract are 1,000 tons $\mathrm{CO}_{2}$ equivalent. We choose time-serial daily settlement price for EUA futures contracts with different delivery dates going from December 2010 to December 2014 in Figure 1. Since the trading of futures contracts with vintages December 2013 and December 2014 were started on April 8, 2008. Considered the continuity and availability of numerical samples, we select date samples cover the period from April 8, 2008 to December 20, 2010 in the Kyoto phrase. The free-risk interest rates are 12-month Euribor.

4.2. Hypothesis Estimation. Actual trading days of emission allowance each year have 255 days, and then we can take 21 days as the benchmark number of a month. Convenience yield of emission allowance can be denoted by options value of spot assets instituted futures assets, and we can estimate monthly options value of convenience yield using the extension of exchange options pricing model. In Figure 2, $\mathrm{OCY}_{1}$ denotes the closest time to maturity of monthly options value of convenience yield, and $\mathrm{OCY}_{2}$ denotes the second closest time to maturity of monthly options value of convenience yield, and the others variables are similarly defined.

In Figure 2, monthly options value of convenience yield of emission allowance exhibits a time-varying trend. On the basis of Chang's empirical results $[8,9]$, options value of convenience yield has a significant option feature. In Table 1 , the mean of monthly options value of convenience yield with 
TABLE 1: Statistical description of monthly options value of convenience yield of emission allowance.

\begin{tabular}{lcccc}
\hline Convenience yield & Mean & Maximum & Minimum & Standard deviation \\
\hline $\mathrm{OCY}_{1}$ & 0.1886 & 1.6670 & 0.0019 & 0.3109 \\
$\mathrm{OCY}_{2}$ & 0.1960 & 2.1288 & -0.0004 & 0.3882 \\
$\mathrm{OCY}_{3}$ & 0.1559 & 2.3885 & -0.0012 & 0.4291 \\
$\mathrm{OCY}_{4}$ & 0.1389 & 1.8049 & -0.0015 & 0.3549 \\
$\mathrm{OCY}_{5}$ & 0.1392 & 1.5784 & -0.0002 & 0.3244 \\
\hline
\end{tabular}

TABLE 2: Regression results between price spread and convenience yield of emission allowance.

\begin{tabular}{lccccc}
\hline Coefficient & OCY $_{1}$ & OCY $_{2}$ & OCY $_{3}$ & OCY $_{4}$ & OCY $_{5}$ \\
\hline$\alpha$ & $-3.759^{* * *}(-1.022)$ & $-2.201^{* * *}(-2.781)$ & $-1.115^{* *}(-1.984)$ & $-0.649^{* *}(-2.131)$ & $-0.491^{* *}(-2.210)$ \\
\hline
\end{tabular}

TABLE 3: Regression results among convenience yield, spot price, futures price, and their volatility.

\begin{tabular}{lcccc}
\hline Coefficient & $\beta_{1}$ & $\beta_{2}$ & $\beta_{3}$ & $\beta_{4}$ \\
\hline $\mathrm{OCY}_{1}$ & $3.372^{* *}(1.027)$ & $-1.179^{* * *}(-2.916)$ & $-3.293^{* *}(-1.003)$ & $1.148^{* * *}(2.979)$ \\
$\mathrm{OCY}_{2}$ & $3.887^{* *}(1.551)$ & $-1.290^{* * *}(-3.881)$ & $-3.791^{* *}(-1.518)$ & $1.243^{* * *}(3.998)$ \\
$\mathrm{OCY}_{3}$ & $3.241^{* *}(2.069)$ & $-1.552^{* * *}(-5.858)$ & $-3.141^{* *}(-2.026)$ & $1.458^{* * *}(5.993)$ \\
$\mathrm{OCY}_{4}$ & $2.969^{* *}(2.402)$ & $-0.427^{* *}(-2.019)$ & $-2.848^{* *}(-2.365)$ & $0.484^{* *}(2.404)$ \\
$\mathrm{OCY}_{5}$ & $2.641^{* * *}(2.779)$ & $-0.163^{* *}(-0.952)$ & $-2.504^{* * *}(-2.733)$ & $0.239^{* *}(1.348)$ \\
\hline
\end{tabular}

Note: in Tables 2 and $3,{ }^{* * * * *}$ denote the $95 \%$, and $99 \%$ confident levels; the number in the parentheses is $t$-statistic values.

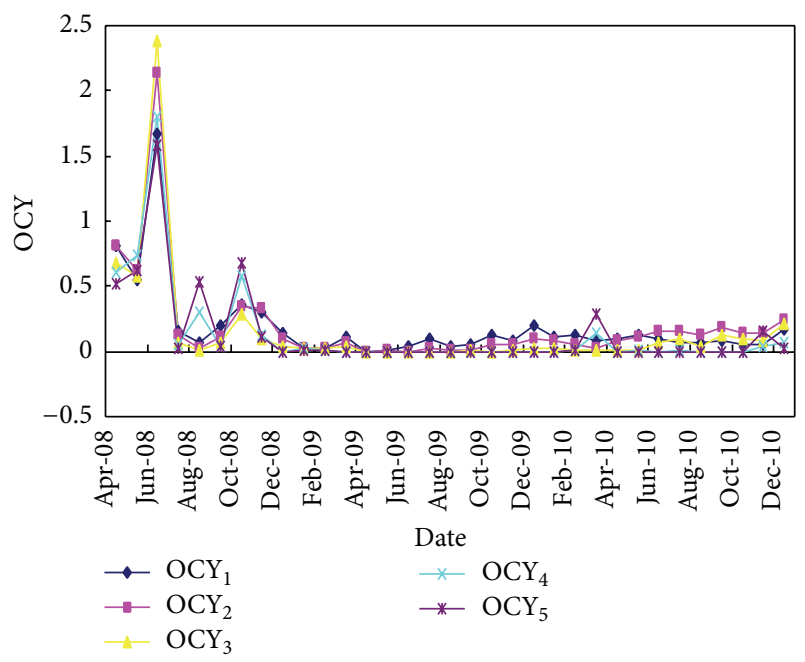

FIGURE 2: Monthly options value of convenience yield of emission allowance.

different maturities is positive; market investors buy spot assets while selling futures contracts with different maturities and then gain the excess investment revenues. Most of monthly options value of convenience yield is positive, and few of monthly options value of convenience yield is negative; these signs show that market investors can gain excess investment revenues using option feature of convenience yield. Monthly options value of convenience yield with different maturities exhibits greater market volatility.
In Table 2, monthly options value of convenience yield is negatively related with price spread between spot and futures assets. Shorten spread signals show that unexpected quantity shock between market supply and demand push greater market demand with the incline of price spread between spot and futures assets and increase spot price of emission allowance, and then spot holders can gain greater monthly options value of convenience yield. These results support Hypothesis 1. The related coefficients between OCY and price spread exhibit a decreasing trend with an increase of time to maturity; unexpected market shocks have greater impacts on futures price with the higher time to maturity; price spread between spot and futures recline and monthly options value of convenience yield significantly increase at the 95\% confident level.

In Table 3, monthly options value of convenience yield for emission allowance is negatively related with futures price and the volatility of spot price, while it is positively related with spot price and the volatility of discounted futures price, and their coefficients are significant at the $95 \%$ confident level. Those empirical results support hypothesis 2 . A good many complex factors bring about low efficiency and overreaction of price in the emissions allowances market and then exert greater market price shock. Price shock exhibits a tremendous difference in time and channels of spot and futures prices in the immature emissions allowances markets. Current emissions allowances markets are weakly effective and then exhibit market bias, transaction cost, and market overreaction. In the immature emissions allowances markets, unexpected market information has a different change speed of spot and futures prices in the short run, and emissions 
allowances markets exhibit a significant lead-lag relationship between spot and futures prices.

\section{Conclusion}

Convenience yield of emission allowance has significant option feature; market investors buy spot assets while selling futures assets and then gain excess investment revenues, and monthly options value of convenience yield exhibits a significantly time-varying trend. Monthly options value of convenience yield is negatively related with price spread between spot and futures assets, and unexpected market shocks promote monthly options value of convenience yield increasing. Convenience yield is significantly related with spot price, futures price, and their volatility at the $95 \%$ confident level. Our empirical results verify that we provide a new approach and methodology to estimate convenience yield value. Market investors can flexibly adjust portfolio policy and then achieve excess investment revenues using options property of convenience yield and information set of unexpected market shocks.

\section{Conflict of Interests}

The author declares that there is no conflict of interests regarding the publication of this paper.

\section{Acknowledgments}

The author is grateful for research support from Center for Research of Regulation and Policy of Zhejiang Province (13JDGZ03YB) and China Statistical Science Research Planning (2013LY125).

\section{References}

[1] A. Kossoy and P. Ambrosi, State and Trends of the Carbon Market 2011, Carbon Finance at the World Bank, Washington, DC, USA, 2010, http://www.carbonfinance.org/.

[2] E. Benz and S. Truck, " $\mathrm{CO}_{2}$ emission allowances trading in Europe-specifying a new class of assets," Problems and Perspectives in Management, vol. 4, no. 3, pp. 30-40, 2006.

[3] E. Benz and S. Trück, "Modeling the price dynamics of $\mathrm{CO}_{2}$ emission allowances," Energy Economics, vol. 31, no. 1, pp. 4-15, 2009.

[4] J. Seifert, M. Uhrig-Homburg, and M. Wagner, "Dynamic behavior of $\mathrm{CO}_{2}$ spot prices," Journal of Environmental Economics and Management, vol. 56, no. 2, pp. 180-194, 2008.

[5] G. Daskalakis, D. Psychoyios, and R. N. Markellos, "Modeling $\mathrm{CO}_{2}$ emission allowance prices and derivatives: evidence from the European trading scheme," Journal of Banking and Finance, vol. 33, no. 7, pp. 1230-1241, 2009.

[6] K. Chang, S.-S. Wang, and J.-M. Huang, "A new N-factor affine term structure model of futures price for $\mathrm{CO}_{2}$ emissions allowances: empirical evidence from the EU ETS," WSEAS Transactions on Business and Economics, vol. 9, no. 2, pp. 81-88, 2012.

[7] K. Chang, S.-S. Wang, P. Ke, H. Yu-Rong, and Y. Zhen, “The valuation of futures options for emissions allowances under the term structure of stochastic multi-factors," WSEAS Transactions on Systems, vol. 11, no. 12, pp. 661-670, 2012.

[8] K. Chang, "Convenience yields and arbitrage revenues of emission allowances between spot and futures," WSEAS Transaction on System, vol. 12, no. 11, pp. 651-660, 2013.

[9] K. Chang and S. S. Wang, "Convenience yields and options value of exchanging futures contracts implied from emissions allowances futures markets," WSEAS Transaction on System, vol. 13, no. 4, pp. 116-129, 2014.

[10] N. T. Milonas and S. B. Thomadakis, "Convenience yields as call options: an empirical analysis," Journal of Futures Markets, vol. 17, no. 1, pp. 1-15, 1997.

[11] A. E. Kocagil, "Optionality and daily dynamics of convenience yield behavior: an empirical analysis," Journal of Financial Research, vol. 27, no. 1, pp. 143-158, 2004.

[12] W. T. Lin and C.-W. Duan, "Oil convenience yields estimated under demand/supply shock," Review of Quantitative Finance and Accounting, vol. 28, no. 2, pp. 203-225, 2007.

[13] R. S. Pindyck, "The dynamics of commodity spot and futures markets: a primer," Energy Journal, vol. 22, no. 3, pp. 1-29, 2001.

[14] S. Z. C. Wei and Z. Zhu, "Commodity convenience yield and risk premium determination: the case of the U.S. natural gas market," Energy Economics, vol. 28, no. 4, pp. 523-534, 2006.

[15] T. Kremser and M. Rammerstorfer, "Convenience yield and risk premium-comparison of the European and US natural gas markets," in Proceedings of the 23rd Australasian Finance and Banking Conference, vol. 11, pp. 1-42, 2010. 

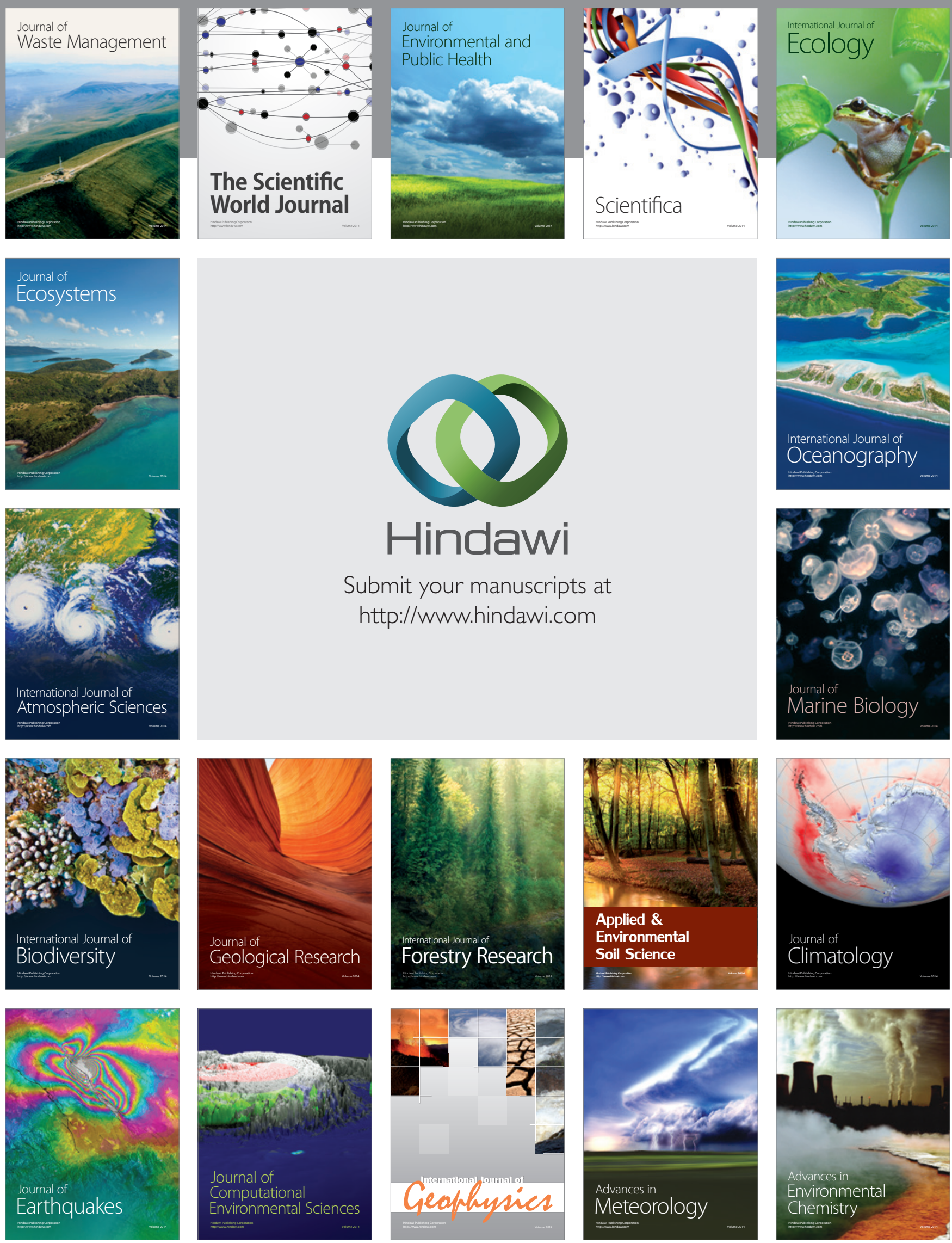